\title{
Dental Route of Administration
}

National Cancer Institute

\section{Source}

National Cancer Institute. Dental Route of Administration. NCI Thesaurus. Code C38197.

Administration of the drug to a tooth or teeth. 